\title{
Physio-Chemical Properties of Malted Sorghum as Material For Mucamalt Using Cashew Apple Juice Extract As Vitamin C Fortifier
}

\author{
${ }^{1}$ Abdulraheem, M.O.,${ }^{2}$ Aberuagba, F., ${ }^{3}$ Okafor, J.O. and ${ }^{4}$ Otaru, A.J.

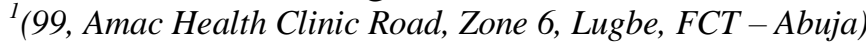 \\ ${ }^{2,384}$ (Department of Chemical Engineering, Federal University of Technology Minna, Nigeria).
}

\begin{abstract}
The search for a local raw material for the production of beverages necessitated the harnessment of cashew extract. The beverage produced is $100 \%$ local contents with easy accessibility to the raw materials, reduced production cost and increased economic revenue of Nigeria. Thus the aim of this research was to harness our abundant natural resources endured by God. Sorghum has a wide range of colors. The best known are the white, yellow, brown and the red types. Although the red type was used because of her high extract yields. The optimization temperature come to play and it was discovered that the best and highest extract yields can only be obtained at temperature between 80 to $85^{\circ} \mathrm{C}$ and the red sorghum meets this criterion. The influence of temperature, time and moisture on the enzyme activity and malting losses of germinated sorghum (Sorghum bicolor) were critically examined. The duration of germination and watering rate had the highest effect on enzyme activity and malting losses respectively. Vitamin $C$ sourced from cashew apple fruits, the apple represents nearly $90 \%$ of the cashew (nut + apple). It is almost entirely edible, with pleasant flavor and aroma and high nutritive value, which is due mainly to high vitamin $C$ and sugar contents. Sorghum used not as adjunct in this Mucamalt production but as main raw material along with Cashew Apple Extract, Vitamin C. However, the availability of the grain and seasonal cashew apple fruit (Between January to April) preservation poses a great problem to the brewing industry. The Mucamalt, a brand of malt drink was as a result of the well blended two local contents of red sorghum bicolor and red elongated cashew apple extract after careful selection through process optimization.
\end{abstract}

Key words: Apple juice, Cashew, Extract, Mucamalt, Nigeria and Sorghum.

\section{Introduction}

Malt drink belongs to the category of brewed drinks that are considered non-alcoholic beverage drink, fortified with vitamin $\mathrm{C}$ and other minerals that are of benefit to human health. Production of this beverage varies from brewery to brewery in the composition of their ingredients but the basic ingredients remain the same. Through the physicochemical properties of carbohydrate malted sorghum which produces fermentable sugars from starch degradation was used and cashew apple fenny as vitamin $C$ fortifier. Vitamins $C, B_{1}, B_{2}, B_{3}$, $\mathrm{B}_{4}$ and $\mathrm{B}_{6}$ are options and apart from their importance to the body building effects, the producer of malt drink use them in their product to attract customers. There are two major sources of vitamin $\mathrm{C}$ namely; synthetic and natural types. The former apart from being more acidic ${ }_{\mathrm{p}} \mathrm{H}$ 2.1-2.6) contains some chemicals that are used as additives in the course of producing them and such chemicals includes heavy metals and oxalic acid that are not friendly to our health while the later is hundred percent natural and is devoid of hazardous additives.

The advantages of sorghum over wheat or barley as major raw materials in brewing cannot be overemphasized. The availability of the cashew apple with wider range, will in no small measure reduce the costs of production, and by extension bring the benefit of reduced costs to the consumers and is gluten-free as the product would not only be cheaper but also available. Physical and chemical characteristics of both malted and unmalted sorghum and cashew apple juice extracts were determined to evaluate their malting, extracting and brewing values. The compatibility of these two, malted sorghum and cashew juice for a large scale production will be determined and analysis against three other common malt drinks in the Nigerian market.

\section{A. Sources of materials}

\section{Research material and methodology}

Sorghum which is the major raw material and a source of carbohydrate were sourced at a local market around Airport Road, Lugbe area of Federal Capital Territory, Abuja, Nigeria. The Cashew being the source of Vitamin $\mathrm{C}$ for the fortification was sourced along Lemu road, Nigeria, the local rice used was gotten also in Bida, Nigeria and the research practical carried out at the National Cereal Research Institutes Badeggi, Niger State, Nigeria. 


\section{B. Grain analysis}

\section{Malting}

The procedures for various tests carried out are described below

The grains was steeped in water, improved with hydrated lime which helped to reduce phenol content from germinated sorghum after the first 8hours the water was drained off and allowed to rest for 1hour, steeped again for another 4hours, the water drained again and rested for 30mins, soaked for another 4hours which completed the steeping process.

During the germination stage of malting, the formation of many enzymes is promoted and is dependent upon the moisture and oxygen content of the grain. The grains were germinated at a regulated temperature of between $20^{\circ} \mathrm{C}$ to $25^{\circ} \mathrm{C}$ for about 5 days. Within this period, the grains were turned twice per day and moisture contents noted and recorded. Plate I shows the terminated malting Sorghum.

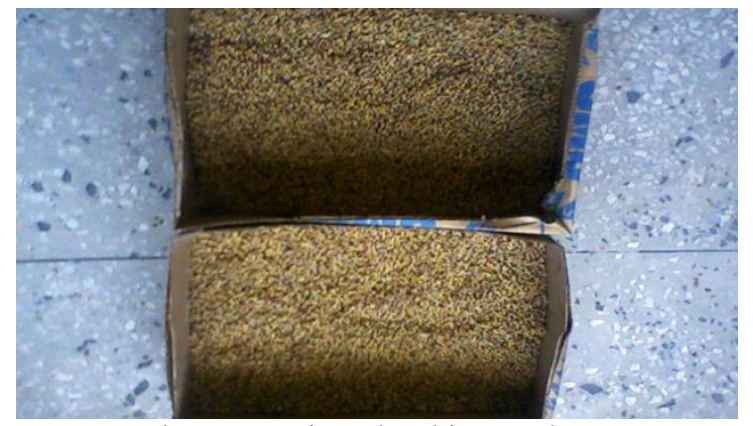

Plate I: Terminated malting sorghum

\section{Termination of germination}

The process was then halted and the malt transferred to a kiln (dryer) at a steady temperature of between $55^{\circ} \mathrm{C}$ to $60^{\circ} \mathrm{C}$ to attain moisture content of $15 \%$. Further reduction of moisture content to between $6-10 \%$ was obtained by raising the temperature of the dryer to $80^{\circ} \mathrm{C}-85^{\circ} \mathrm{C}$ (optimum temp.) for maximum extract yield and stable state for long storage purpose

\section{Germinating capacity}

At the germination temperatures of 20,25 , and $30^{\circ} \mathrm{C}$ used in the malting process of the cereal (sorghum), production of reducing sugars and that of free amino nitrogen (FAN) is the result. The germinating capacity of the sample $=(\mathrm{a} / 500) \times 100=(464 / 500) \times 100=92.8 \%=\mathbf{9 2 . 8 \%}$ Where: $\mathrm{a}=$ number of germinated sorghum after 96hrs.

\section{Ash present}

$2 \mathrm{~g}$ of the milled sorghum sample was weighed and put in a porcelain glass the content is then placed in the Gallenkamp (furnace) at a temperature of $500^{\circ} \mathrm{C}$ and for a period of $6 \mathrm{hrs}$. The oven was turned off and allowed to cool down to $150^{\circ} \mathrm{C}$. The porcelain was then transferred to desiccators and allowed to rest for about 30mins, the weight was then taken as follow;

Percentage ash $=(\mathrm{b}-\mathrm{c}) 10,000 /(100-\mathrm{w}) \mathrm{a} \quad$ Where: $\mathrm{a}=$ weight of sorghum sample $(2 \mathrm{~g})$

$\mathrm{b}=$ weight of sample + porcelain

$\mathrm{c}=$ weight of ash + porcelain

Percentage $=(43.974-43.9415)\{10,000 /(100-7.6) 2\}$

$$
=\{(0.00325) 10,000\} /(184.8)=0.175
$$

Malting loss: 1000 pieces of grains was counted and weighed, before and after malting, It was then compared as follow;

Percentage malting loss on dried basis is $100\left(\mathrm{TSW}_{1}-\mathrm{TSW}_{2}\right) / \mathrm{TSW}_{1}$

Where: $\mathrm{TSW}_{1}=$ thousand sorghum weight on dry basis

$\mathrm{TSW}_{2}=$ thousand sorghum weight of polished malt

Percentage malting loss $=\{100(43.59-39.44)\} / 43.59=415 / 43.59=9.5 \%$

\section{Cashew apple juice extraction}

The plunged cashew was carefully selected to remove the infected and damaged ones, average weight of the cashew taken along with the cashew nut and without the nut. About ten (10) samples were picked randomly and the following weights are obtained without the nuts. Average weights of four 
types of cashew apple fruit: Red elongated $=82.88 \mathrm{~g}$, Red round $=63.8 \mathrm{~g}$, Yellow elongated $=83.5 \mathrm{~g}$ and Yellow round $=64.02 \mathrm{~g}$
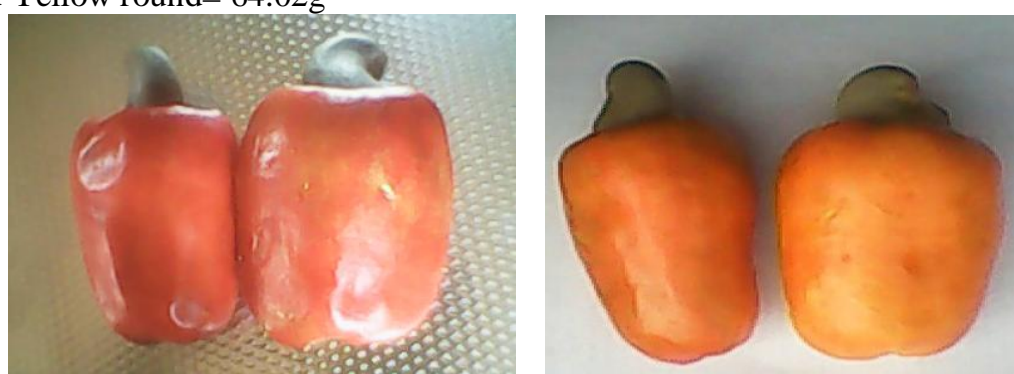

Plate (a) Red round cashew apple fruit Plate (b) Red elongated cashew apple fruit

Cashew Juice provides five times the Vitamin $C$ of orange juice. In addition, Cashew Fruit Juice contains healthy ingredients, including Vitamins $\mathrm{B}_{1}, \mathrm{~B}_{2}$, and $\mathrm{B}_{3}$, calcium, and iron and beta carotene. The health benefits of the cashew drink include soothing sore throats and strengthening the immune system. The juice is full of Natural Vitamins and Minerals, and contains Disease Fighting Anti-Bacterial Agents.
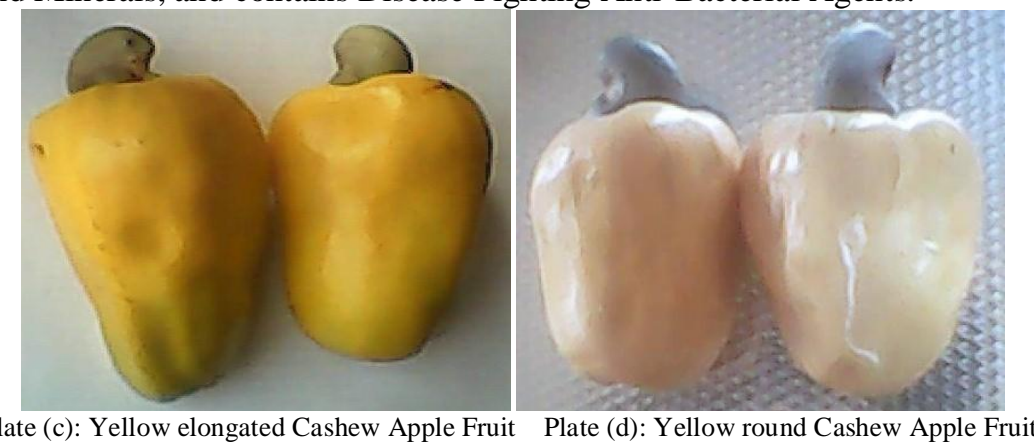

\section{Cashew extract modification.}

Rice gruel is another clarifying agent for raw cashew apple juice which is another contribution of Indian research scientists. And of the three agents discussed, rice gruel happened to be the quickest way to obtain clear cashew apple juice - with the simplest of means: residual water from the cooking of rice. The clarified cashew apple juice can then be refrigerated and kept for good three days. Otherwise, if kept at room temperature $\left( \pm 30^{\circ} \mathrm{C}\right)$, it should be consumed within 24 hours, in order to prevent fermentation from occurring.

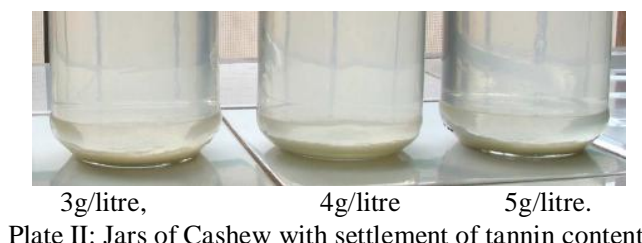

In the above plate three small jars of 3litres, 4litres and 5litres respectively were used to determine the ideal rice gruel solution strength. Visual clarity and speed of tannin precipitation are key criteria in the selection of the solution strength.

\section{E. Brewing process}

$2.5 \mathrm{~kg}$ was weighed from the milled malt, along with 7litres of hot water, fed into cooking bowl, and 3.75 grams of $\mathrm{CaCl}_{2}$ and $3.75 \mathrm{grams}$ of brew plaster were added, the mixture were then heated to $50^{\circ} \mathrm{C}$, at this temperature enzymes; termamyl and fungamyl are added at $180 \mathrm{mls}$ and $90 \mathrm{mls}$ (quantity) respectively and allowed to rest. Without the protection of Calcium ions a-amylase is rapidly destroyed at normal mashing temperatures. When Calcium is present in sufficient amounts the enzyme is stable at above sparging temperatures, only then being finally destroyed in the Copper.

Alpha-amylase is used in ethanol production to break starches in grains into fermentable sugars. The first step in the production of high-fructose corn syrup is the treatment of cornstarch with alpha-amylase, producing shorter chains of sugars called oligosaccharides. An alpha-amylase called "Termamyl", sourced from Bacillus licheniformis, is also used in some detergents, especially dishwashing and starch-removing detergents. The natural enzyme produced in the wort that will cleave this link is limit dextrinase, but this is highly heat liable and is destroyed completely at mashing temperatures. 
The use of additional enzymes is common throughout the brewing industry, and is greatly beneficial. It aids Mash Tun run off by reducing wort viscosity, also improving subsequent malt fine ability and filterability. Amylases are also used, typically where the use of adjuncts may dilute the availability of enzymes in the Mash Tun.

The infusion process mixes the malt with hot water to maintain a uniform temperature until starch conversion is complete and finally temperature is raised to $100^{\circ} \mathrm{C}$ and boiled for $20 \mathrm{mins}$ vigorously. The Lauter tun, which separates the insoluble grain residues from the mash, cloth sieve was employed to do same, the separation and the finished product of mashing is grain slurry, called mash. Various other filter agents, such as polypropylene fibers can also be used. Some breweries use strain masters, which are a variation of lauter tuns. The spent grain obtained after the filtration which is spargled with water at $78^{\circ} \mathrm{C}$, can be sold as animal feed after drying and nourished with other vitamins. The product of the filtration is called wort, the ${ }_{\mathrm{P}} \mathrm{H}$ is taken as 5.4 The wort is transferred to another cooking put where it is boiled vigorously for about 2 hours, the essence of the long boiling is to achieved the following; stops the starch -to-sugar conversion, sterilizes the wort, precipitates hydrolyzed proteins, concentrates the wort by evaporating excess water and effects chemical changes that affect end product flavor.

Adjuncts such as, (267grams of sugar), caramel are added to increased the gravity of wort and black coloration of the final product malt. The caramels required or added depend on individual brewery. The mixture was allowed to settle and cooled down until there was a clear filtrate and sludge. Carefully, the filtrate is removed and wahtmann filter paper is used to filter the filtrate to obtained clearer final product (malt). 400mls of the malt obtained was inoculated with $100 \mathrm{mls}$ of cashew extract of about $10 \%$ concentration. The inoculated malt was then transferred onto water bath under tight sealed and regulated at $70^{\circ} \mathrm{C}$ for a period of $1 \mathrm{hr}$, there was a coagulant formed at the bottom of the bottle, the malt was filtered to removed the sediment been formed at the bottom of the bottle and transferred again to the water bath for another $70^{\circ} \mathrm{C}$, this is done in order to sterilized the malt, for long live span and preservation.

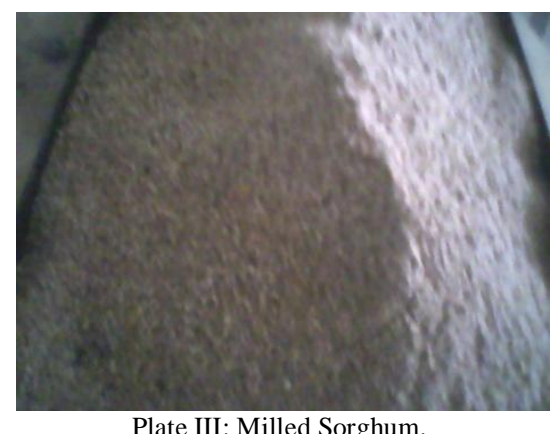

Plate III: Milled Sorghum.

\section{F. Check for saccharification}

Some quantity of mash were taken and filtered using fine whatmann filter paper, time of filtration is noted, the filtrate is then transferred on to crucible and checked for saccharification by adding drop(s) of iodine solution. Filtration of the whole lots continues and the solute obtained is known as wort. After the first filtration, the substrate is further sparged (washed) with hot water at $78^{\circ} \mathrm{C}$ to remove left over sugar or wort, this could also be describe as leaching out of aqueous extract from a mash filter.

\section{G. Diastatic power using Windisch-Kolbach method}

Diastatic power is a measure of how much starch-converting enzyme in any given malt contains and is measured in degrees Lintner. As a general rule of thumb, you want to make sure your mash averages 70 Linter or above. It is good to know that heat destroys diastatic power, if the temperature targeting is a bit off. The suggestion here is that the diastatic power be keep above 100. Forty five grams of milled malt was weighed, transferred into a beaker mixed with $180 \mathrm{ml}$ of distilled water at $40^{\circ} \mathrm{C}$, the beaker and its contents were then transferred to water bath maintained at the same temperature for an hour. The contents were made up to $295 \mathrm{mls}$ with distilled water of about $32^{\circ} \mathrm{C}$, room temperature. In addition $70,15,15 \mathrm{mls}$ of distilled water respectively were successfully used to sparge the contents and out of which $50 \mathrm{mls}$ is used for the analysis. Two conical flasks of $200 \mathrm{mls}$ were set aside, one for the experiment and the other as blank, into which $100 \mathrm{mls}$ of $2 \%(\mathrm{w} / \mathrm{v})$ starch were added, after some minutes $5 \mathrm{mls}$ of acetate buffer solution were also added to the two separate samples, one was placed in the water bath at $20^{\circ} \mathrm{C}$ for $20 \mathrm{mins}$, with $5 \mathrm{mls}$ of malt extract introduced into the flask under continuous stirring, the mixture ${ }_{\mathrm{P}} \mathrm{H} 5.58$ was obtained. The two flask volumes were then made up to $200 \mathrm{mls}$ with distilled water and mixed thoroughly, from each flask $50 \mathrm{mls}$ were pipette into an Erlenmeyer flask after which $25 \mathrm{mls}$ of $0.1 \mathrm{~N}$ Iodine solution and $3 \mathrm{mls}$ of $1 \mathrm{~N} \mathrm{NaOH}$ were added and covered with lid glasses. 
At about $15 \mathrm{mins}$, the flask contents were acidified with $4.5 \mathrm{mls}$ of $1 \mathrm{~N} \mathrm{H}_{2} \mathrm{SO}_{4}$, the excess iodine is titrated with $0.1 \mathrm{~N}$ Sodium thiosulphate.

\section{H. Wort sterilization}

Wort refers to the filtrate obtained from the filtered mash before and after sparging, this wort is boiled to sterilize the wort composition and to extract the desirable compounds their present. This boiling will last for between 1hour to 1.5 hours when the adjuncts such as, sugar syrup, caramel, Cashew fruit juice extract, AMG/Hi-Tempase and fungamyl are added to achieve the following:

1. Homogenization of the caramel as colourant

2. Colour and Odour development

3. Concentration of wort

4. Sterilisation of wort

5. Drive off of the undesirable volatile gases such as DMS and $\mathrm{H}_{2} \mathrm{~S}$

6. Sugar syrup to improve wort gravity

7. Termination of the carry-over enzymes from mash.

8. Precipitation of undesirable protein.

9. Concentrate of Cashew fruit juice is blended with the prepared wort.

\section{Malt production}

The whole content is further cooled down to temperature of between $4^{\circ} \mathrm{C}$ and $6^{\circ} \mathrm{C}$ and final filtration carried out to prepare the product for packaging in either bottle or can for proper storage. However the final analysis is done and regulated to conform to set standard which depends on the set standard of the brand brewery. Priming in the brewery industry is the addition of sugar to wort in the production of either beer or malt and vitamin $\mathrm{c}$ added also depend on individual brewery. The resulting malt after boil is cooled down to a very low temperature to allow other heavy particles to form sedimentation at the bottom of the containing vessel in form of slurry. It is then filter and the following parameters confirmed; $\mathrm{pH}$, Gravity, Saccharification and colour.

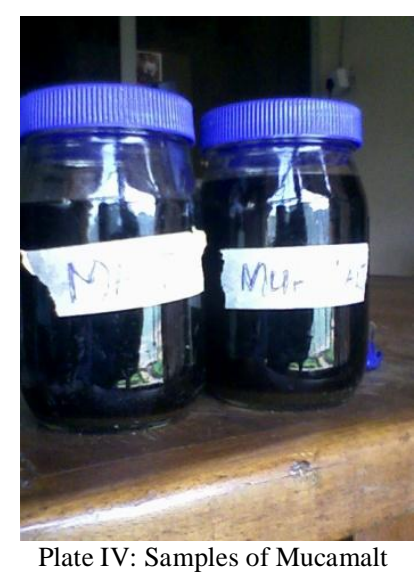

\section{J. Percentage extract yield}

Extract yield is an important economic factor in evaluating raw grain for malting and was determined; it is an indication on how much of the original grain comes into the extract. Fifty grams of the milled malt is weighed and poured in the beaker, $200 \mathrm{ml}$ of distilled water is added at $45^{\circ} \mathrm{C}$ the contents is then transferred to hot plate regulated to $45^{\circ} \mathrm{C}$ with stirring set at $100 \mathrm{rpm}$ and allowed for $30 \mathrm{mins}$, after which the temperature is increased to $70^{\circ} \mathrm{C}$ from $45^{\circ} \mathrm{C} ; 1 \mathrm{~min} / 1^{\circ} \mathrm{C}$ for $25 \mathrm{mins}$. $100 \mathrm{mls}$ of distilled water was later added at $70^{\circ} \mathrm{C}$ this mixture (mash) was allowed to rest for an hour maintaining this temperature it was then cooled down to $20^{\circ} \mathrm{C}$ with cold water. The total volume raise up to $450 \mathrm{mls}$ with distilled water stirred well and filtered using filter paper. The filtrate was transferred into measuring cylinder at $20^{\circ} \mathrm{C}$; the hydrometer was inserted and recorded reading taken.

Specific gravity of wort $=1.033$

From the Extract Table $=8.29(\mathrm{~g} / 100 \mathrm{~g})$

Extract in $\mathrm{g} / 100 \mathrm{~mL}, \mathrm{E}_{\mathrm{w}}=8.55$

The extract yield on air-dry sorghum is $\mathrm{E}_{\mathrm{n}}=\mathrm{P}(\mathrm{w}+800) /(100-\mathrm{P}) \%$ by wt

The extract yield on dry sorghum is $\mathrm{E}_{\mathrm{d}}=100 \mathrm{E}_{\mathrm{n}} /(100-\mathrm{w}) \%$ by wt

En $=8.55(7.4+800) /(100-8.55) \%$ by wt $=6,903.27 / 91.45=75.49 \%$ 


$$
\begin{aligned}
\mathrm{Ed} & =(100 \times 75.49) /(100-7.4) \% \\
& =7,439 / 92.6=81.52 \%
\end{aligned}
$$

\section{K. Optimization process}

Fractional conversion (or simply conversion) is a convenient variable often used in place of concentration in engineering work. The results will be presented in terms of both $\mathrm{C}_{\mathrm{A}}$ and $\mathrm{X}_{\mathrm{A}}$.

$$
\begin{aligned}
& \mathrm{C}_{\mathrm{A}}=\frac{\mathrm{NA}}{\mathrm{V}}=\frac{\mathrm{NAO}(1-\mathrm{XA})}{\mathrm{V}}=\mathrm{C}_{\mathrm{AO}}(1-\mathrm{XA}) \\
& \text { And } \\
& -\mathrm{dC}_{\mathrm{A}}=\mathrm{C}_{\mathrm{AO}} \mathrm{dXA} \\
& \frac{\mathrm{dXA}}{\mathrm{dt}}=\mathrm{K}(1-\mathrm{XA}) \\
& \text { Rearranging and integrating } \\
& \int \frac{\mathrm{dXA}}{1-\mathrm{XA}}=\mathrm{K} \int \mathrm{dt} \\
& -\ln (1-X A)=\mathrm{Kdt}
\end{aligned}
$$

\section{Finishing}

Two methods are applicable in the production of a finished product from the flavoring syrup. First, the syrup is diluted with water and the product is cooled, carbonated, and bottled. In the second method, precise amount of syrup is measured to each bottle, fills it with carbon dioxide. In either case, the sugar content will reduced in the finished beverage.

\section{Product preservation/carbonation}

Gases are used for preservation, ripening, spoilage prevention, freezing, chilling, carbonation, and many more applications. Carbonation is a phenomenon in which carbon dioxide gas is suspended in water, creating small bubbles. It can occur both naturally and artificially, as a result of the introduction of carbon dioxide to a liquid. This phenomenon is what makes soft drinks bubbly and fizzy, although the fizzy sensation is actually not caused by the bubbles themselves, but rather by the chemicals which make the bubbles. There are a number of reasons for people to use carbonation in the preparation of beverages. One thing about carbonation is that it drives out the oxygen, which can make a beverage shelf stable as long as it is sealed, keeping microbes which need oxygen to survive out.

\section{N. Pasteurization}

Pasteurization is a way of food preservation, it extend her longevity (shelve life) which keep it for longer use, and these could be carried out in different ways. Beverages or Beer pasteurization is the application of heat to the products to enhance its preservation by minimizing harmful micro-organisms. A prerequisite for perfect pasteurization is sufficient heating period at temperatures below $100^{\circ} \mathrm{C}$, the duration of which depends on the characteristic and the ${ }_{\mathrm{p}} \mathrm{H}$ value of the product to be treated. The product must be immediately cooled when heating were completed/finished to prevent any quality loss.

\section{Results and discussion}

$\begin{array}{lc}\text { Results of the analysis of the compositions of red Sorghum grains (\%) } \\ \text { Embryo } & 5 \\ \text { Endosperm } & 88 \\ \text { Pericarp-testa } & 7 \\ \text { Husk } & - \\ \text { Starch } & 64 \% \\ \text { Nitrogen } & 1.26^{\wedge} \\ \text { Lipid/fat } & 12.5 \% \\ \text { 3-D-glucan } & \text { Negligible } \\ \text { Ash } & 0.175 \% \\ \text { Starch gelatinization temperature } & 65^{\circ} \mathrm{C} \\ \text { Starch solubility in } 100^{\circ} \mathrm{C} \text { water } & \text { Soluble } \\ \text { Amyl pectin } & 3.5 \% \\ \text { Amylase } & 12.8 \%\end{array}$


The Percentage moisture content of dry sample of white and red before malting are $20 \%$ and $18.5 \%$ respectively and the corresponding value after malting are given $36.58 \%$ (white) and $33.85 \%$ (red). This shows that at same condition, red sample has high absorbing ability which could reduce the steeping period and save time. Ash present $=0.175$

Germinating capacity is a good quality and attributes for the cereal because it implies that variation in temperature during the malting of sorghum, especially when malting temperature is difficult to control, and also reflecting temperature variations, which was still obtained as $92.8 \%$ and percentage malting loss $=9.5 \%$.

The enzymes amyl pectin $3.5 \%$ and amylase $12.8 \%$ are supportive enzymes generated during malting and enhance in the breakdown of starch bond with the addition of termamyl and hi-tempase enzymes to achieve saccharification of the starch to simple sugar. The sorghum is a glucan free as also shown above which is an advantage over other carbohydrate producing grain and since some people are allergy to glucan thus limit the possible consumption to few but with this development sorghum is highly favor for the production of nonalcoholic drinks. Starch presence of $64 \%$ is not too bad but can be adjusted with some adjunct such as maize grit. Starch gelatinized at $65^{\circ} \mathrm{C}$ and soluble in water at $100^{\circ} \mathrm{C}$. Also the Nitrogen present is $1.26^{\wedge}$

Table 1 Extract yields

\begin{tabular}{|c|c|c|c|c|c|c|c|c|c|c|}
\hline S/No & $\begin{array}{l}\text { Temp. } \\
{ }^{\circ} \mathrm{C}\end{array}$ & $\begin{array}{l}\text { Moist } \\
1^{\text {st }} \\
1 \mathrm{hr}\end{array}$ & $\begin{array}{l}\begin{array}{l}\text { Moist } \\
2^{\text {nd }}\end{array} \\
1 \mathrm{hr}\end{array}$ & $\begin{array}{l}\text { Moist } \\
3^{\text {rd }} \\
1 \mathrm{hr}\end{array}$ & $\begin{array}{l}\text { Moist } \\
4^{\text {th }} \\
1 \mathrm{hr}\end{array}$ & $\begin{array}{l}\text { Total \% } \\
\text { Moisture } \\
\text { Loss }\end{array}$ & $\begin{array}{l}\text { \% Moisture } \\
\text { content }\end{array}$ & $\begin{array}{l}\text { Gewichts- } \\
\text { verhaltnis } \\
20 / 20^{\mathrm{C}} \\
\text { \% Extract } \\
\text { yields }\end{array}$ & $\mathbf{S}_{\mathbf{L}}$ & $\begin{array}{l}\text { Gewicht } \\
\% \mathrm{~g} \text { in } \\
100 \mathrm{ml} \\
\text { bei s20 }\end{array}$ \\
\hline \multirow[t]{2}{*}{1.} & $40 \mathrm{R}$ & & & & & & & 1.0108 & & 2.73 \\
\hline & $\mathrm{W}$ & & & & & & & 1.094 & & 2.41 \\
\hline \multirow[t]{2}{*}{2.} & $45 \mathrm{R}$ & & & & & & & 1.012 & & 3.15 \\
\hline & $\mathrm{W}$ & & & & & & & 1.011 & & 2.85 \\
\hline \multirow[t]{2}{*}{3.} & $50 \mathrm{R}$ & 8.43 & 6.2 & 4.59 & 2.41 & 21.63 & 12.22 & 1.014 & & 3.57 \\
\hline & $\mathrm{W}$ & 8.16 & 6.15 & 4.13 & 2.3 & 20.74 & 15.84 & 1.013 & & 3.20 \\
\hline \multirow[t]{2}{*}{4.} & $55 \mathrm{R}$ & 8.74 & 6.81 & 5.0 & 3.17 & 23.72 & 10.13 & 1.017 & & 4.33 \\
\hline & $\mathrm{W}$ & 8.84 & 6.97 & 5.25 & 3.60 & 24.66 & 11.92 & 1.015 & & 3.83 \\
\hline \multirow[t]{2}{*}{5.} & $60 \mathrm{R}$ & 9.07 & 7.59 & 4.37 & 3.64 & 24.67 & 9.18 & 1.020 & & 5.08 \\
\hline & W & 8.46 & 7.38 & 4.33 & 3.49 & 23.66 & 12.92 & 1.018 & & 4.58 \\
\hline \multirow[t]{2}{*}{6.} & $65 \mathrm{R}$ & 8.47 & 7.43 & 5.03 & 3.50 & 24.43 & 9.42 & 1.023 & & 5.83 \\
\hline & W & 8.35 & 7.29 & 4.99 & 3.29 & 23.92 & 12.66 & 1.020 & & 5.08 \\
\hline \multirow[t]{2}{*}{7.} & $70 \mathrm{R}$ & 10.1 & 8.45 & 7.76 & & 26.32 & 7.53 & 1.025 & & 6.32 \\
\hline & W & 10.0 & 8.21 & 7.43 & & 25.66 & 10.92 & 1.023 & & 5.83 \\
\hline \multirow[t]{2}{*}{8.} & $75 \mathrm{R}$ & 12.1 & 8.55 & 6.31 & & 24.93 & 8.92 & 1.030 & & 7.56 \\
\hline & W & 12.1 & 8.86 & 6.72 & & 27.68 & 8.90 & 1.025 & & 6.32 \\
\hline \multirow[t]{2}{*}{9.} & $80 \mathrm{R}$ & 13.1 & 9.82 & 2.70 & & 25.57 & 8.28 & 1.033 & & 8.29 \\
\hline & W & 13.5 & 9.89 & 2.98 & & 26.32 & 10.26 & 1.030 & & 7.56 \\
\hline \multirow[t]{2}{*}{10.} & $85 \mathrm{R}$ & 13.2 & 10.21 & 3.30 & & 26.71 & 7.14 & 1.033 & & 8.29 \\
\hline & W & 13.6 & 10.45 & 4.05 & & 28.10 & 8.48 & 1.030 & & 7.56 \\
\hline \multirow[t]{2}{*}{11.} & $90 \mathrm{R}$ & & & & & & & 1.029 & & 7.43 \\
\hline & W & & & & & & & 1.024 & & 6.10 \\
\hline \multirow[t]{2}{*}{12.} & $95 \mathrm{R}$ & & & & & & & 1.024 & & 6.12 \\
\hline & W & & & & & & & 1.022 & & 5.67 \\
\hline \multirow[t]{2}{*}{13.} & $100 \mathrm{R}$ & & & & & & & 1.023 & & 5.89 \\
\hline & W & & & & & & & 1.018 & & 4.53 \\
\hline
\end{tabular}

Table 2 Extract yields at varying temperature

\begin{tabular}{|c|c|c|c|c|c|}
\hline S/NO. & Temp. $\mathbf{T}\left({ }^{\circ} \mathrm{C}\right)$ & $\begin{array}{l}\text { Extract yield } \\
\text { (From Table) }\end{array}$ & Fraction (Xa) & $(1-X a)$ & $-\ln (1-X a)$ \\
\hline \multirow[t]{2}{*}{1.} & $\begin{array}{ll}40 & \mathrm{R}\end{array}$ & 2.73 & 0.273 & 0.727 & 0.319 \\
\hline & W & 2.41 & 0.241 & 0.759 & 0.276 \\
\hline \multirow{2}{*}{2.} & $45 \quad \mathrm{R}$ & 3.15 & 0.315 & 0.685 & 0.378 \\
\hline & W & 2.85 & 0.285 & 0.715 & 0.335 \\
\hline \multirow{2}{*}{3.} & $50 \quad \mathrm{R}$ & 3.57 & 0.357 & 0.643 & 0.442 \\
\hline & $\mathrm{W}$ & 3.20 & 0.320 & 0.680 & 0.386 \\
\hline \multirow[t]{2}{*}{4.} & $55 \mathrm{R}$ & 4.33 & 0.433 & 0.567 & 0.567 \\
\hline & $\mathrm{W}$ & 3.73 & 0.373 & 0.627 & 0.467 \\
\hline \multirow[t]{2}{*}{5.} & $60 \mathrm{R}$ & 5.08 & 0.508 & 0.492 & 0.709 \\
\hline & $\mathrm{W}$ & 4.58 & 0.458 & 0.542 & 0.612 \\
\hline \multirow[t]{2}{*}{6.} & $65 \mathrm{R}$ & 5.83 & 0.583 & 0.417 & 0.875 \\
\hline & W & 5.08 & 0.508 & 0.492 & 0.709 \\
\hline \multirow[t]{2}{*}{7.} & $70 \mathrm{R}$ & 6.32 & 0.632 & 0.368 & 1.000 \\
\hline & W & 5.83 & 0.583 & 0.417 & 0.875 \\
\hline 8. & $75 \quad \mathrm{R}$ & 7.56 & 0.756 & 0.244 & 1.411 \\
\hline
\end{tabular}


Physio-Chemical Properties Of Malted Sorghum As Material For Mucamalt Using Cashew Apple

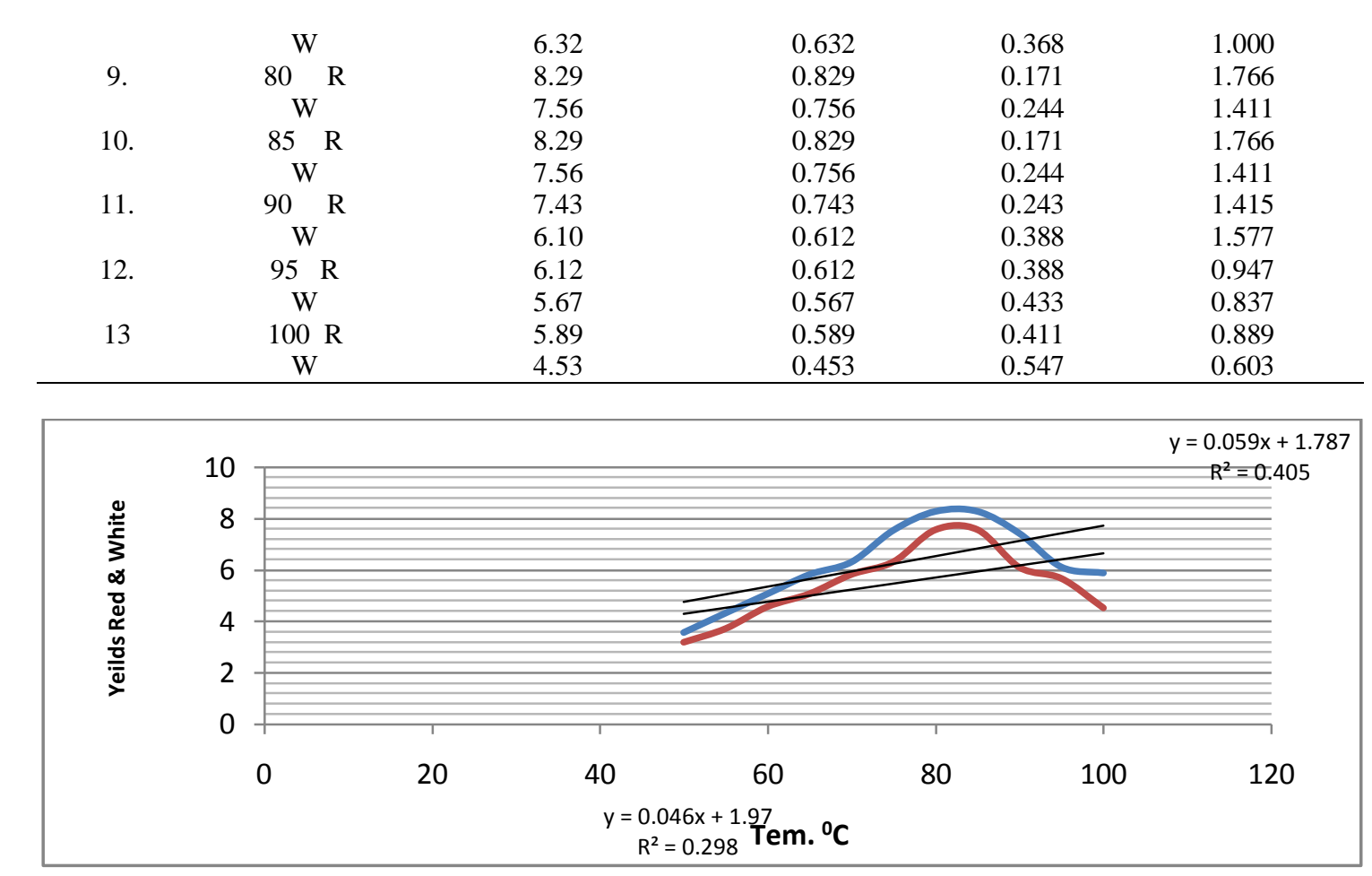

Figure 1: Graph of Extract yields against Temperature $\left({ }^{\circ} \mathrm{C}\right)$

$\mathrm{Y}=0.059 \mathrm{x}+1.787 \mathrm{R}^{2}=0.405, \mathrm{R}=0.636$

$Y=0.046 x+1.97 R^{2}=0.298, R=0.547$

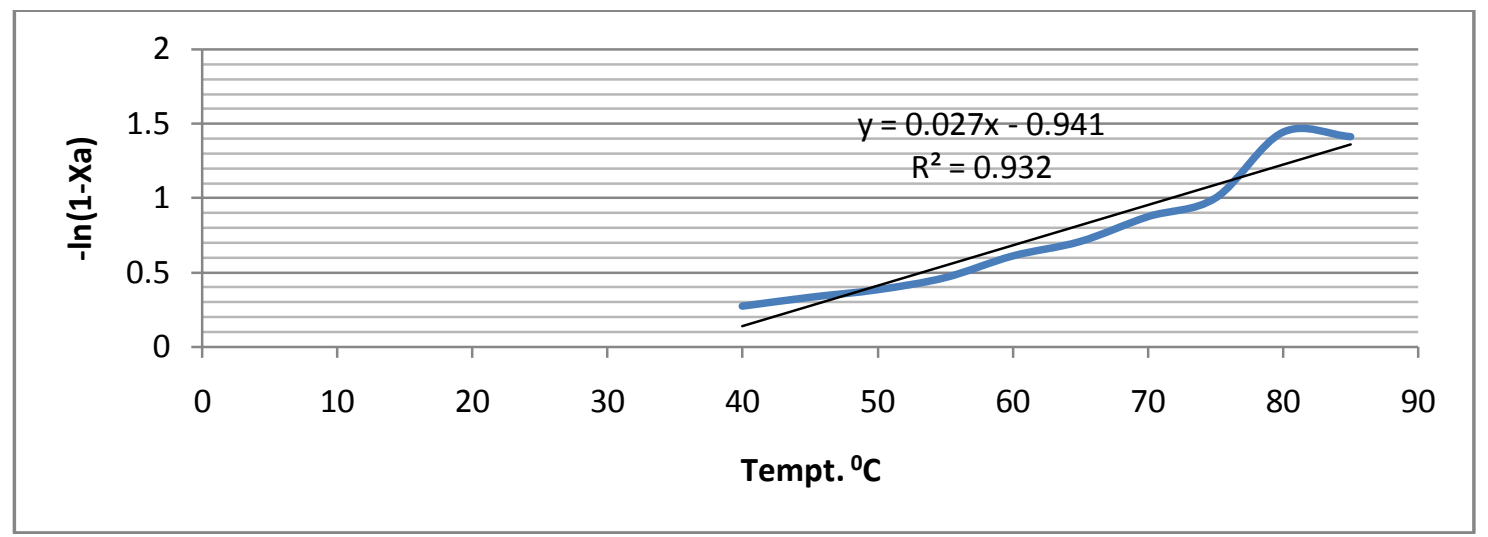

Figure 2 Graph of $-\ln (1-\mathrm{Xa})$ against Tempt. $\left({ }^{0} \mathrm{C}\right)$ : White sample a (1st Order Kinetic) $\mathrm{y}=0.027 \mathrm{x}-0.941, \mathrm{R}^{2}=0.932, \mathrm{R}=0.965$

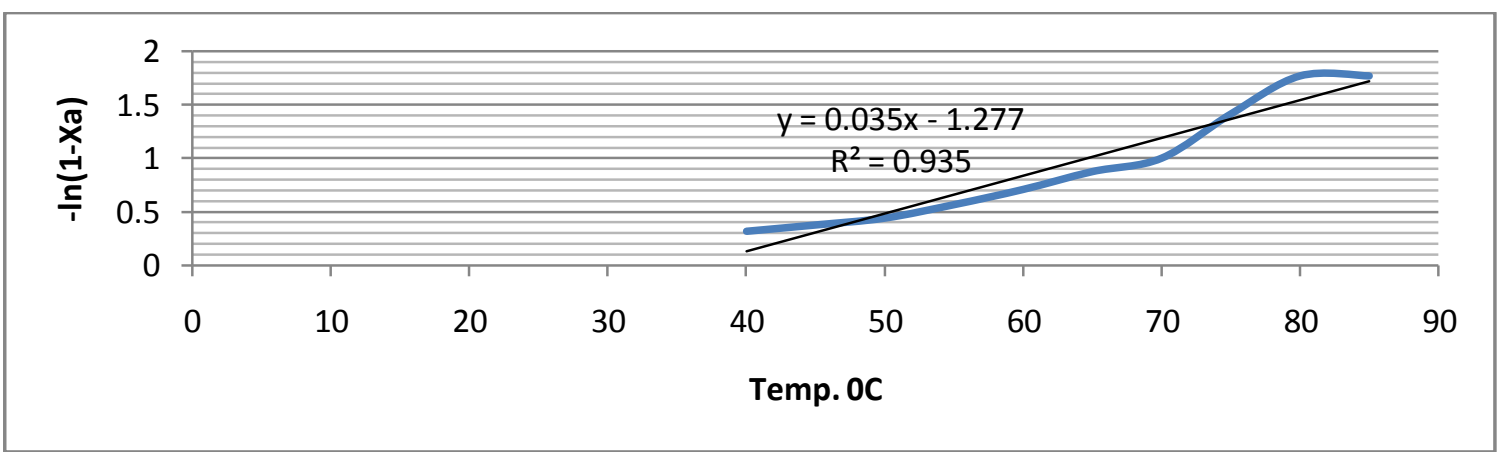

Figure 3 Graph of: - $\ln (1-\mathrm{Xa})$ against Tempt. $\left({ }^{0} \mathrm{C}\right)$ : Red sample a (1st Order Kinetic) 
$\mathrm{y}=0.035 \mathrm{x}-1.277, \mathrm{R}^{2}=0.935, \mathrm{R}=0.967$

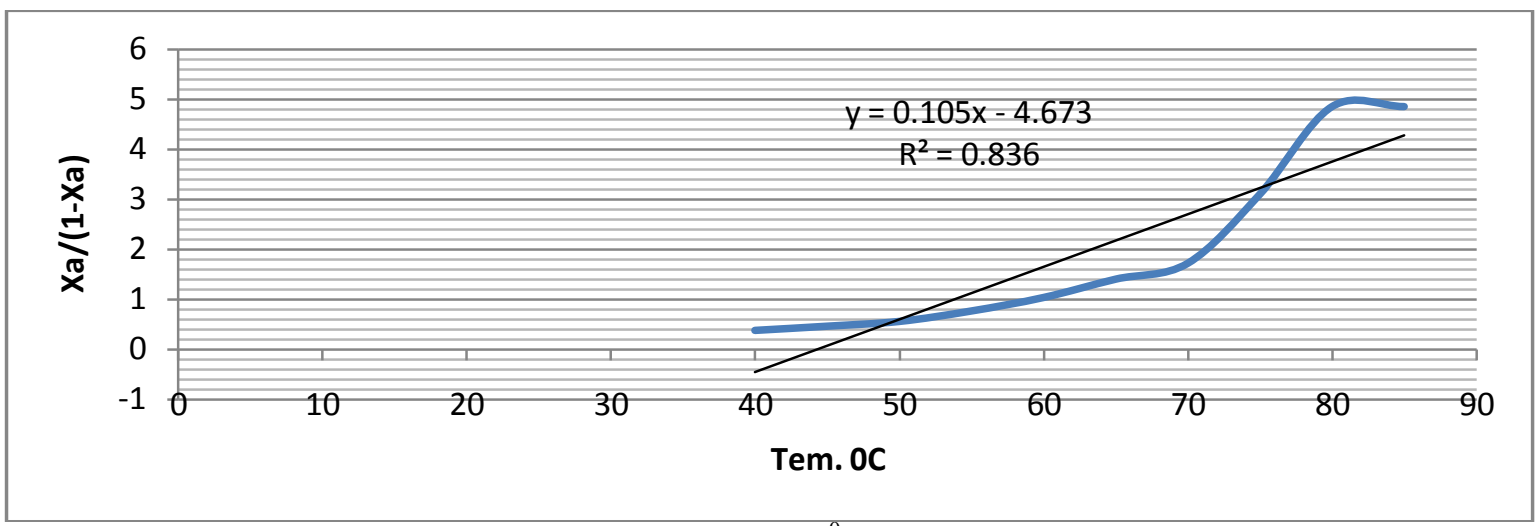

Figure 4: Graph of Xa/(1-Xa) against Tempt. $\left({ }^{0} \mathrm{C}\right)$ Red sample b (2nd Order Kinetic) $\mathrm{y}=0.105 \mathrm{x}-4.673=\mathrm{R}^{2}=0.836, \mathrm{R}=0.914$

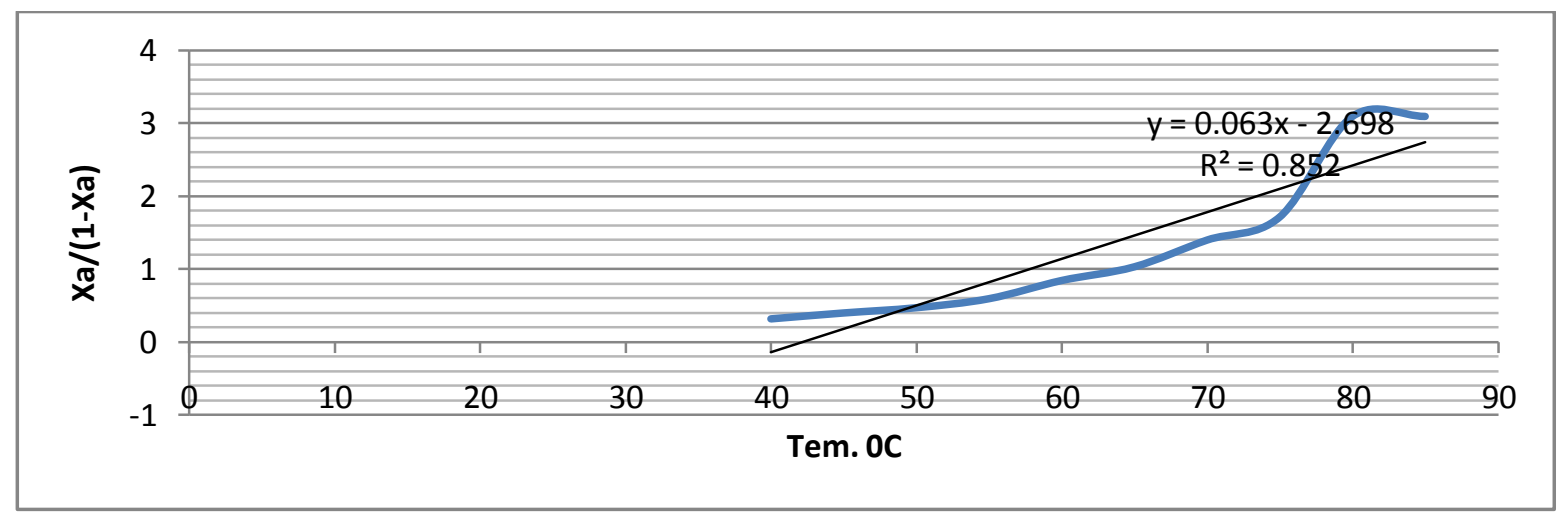

Figure 5: Graph of Xa/(1-Xa) against Tempt. $\left({ }^{0} \mathrm{C}\right)$ White sample b (2nd Order Kinetic) $\mathrm{y}=0.063 \mathrm{x}-2.698=\mathrm{R}^{2}=0.852, \mathrm{R}=0.923$

Optimization process was employed to test among the available factors and variables to arrived at the best and applicable method in achieving the set objective, first order rate of reaction was employed and this was tested below:

Table 3 First and Second Order Kinetics for Extract yields

\begin{tabular}{|c|c|c|c|c|c|}
\hline S/NO. & Temperature $\left({ }^{\circ} \mathrm{C}\right)$ & Fraction $(\mathrm{Xa})$ & (1-Xa) & $-\ln (1-X a)$ & $\mathrm{Xa} /(1-\mathrm{Xa})$ \\
\hline \multirow[t]{2}{*}{1.} & 40 & 0.273 & 0.727 & 0.319 & 0.376 \\
\hline & & 0.241 & 0.759 & 0.276 & 0.318 \\
\hline \multirow[t]{2}{*}{2.} & 45 & 0.315 & 0.685 & 0.378 & 0.460 \\
\hline & & 0.285 & 0.715 & 0.335 & 0.399 \\
\hline \multirow[t]{2}{*}{3.} & 50 & 0.357 & 0.643 & 0.442 & 0.555 \\
\hline & & 0.320 & 0.680 & 0.386 & 0.471 \\
\hline \multirow[t]{2}{*}{4.} & 55 & 0.433 & 0.567 & 0.567 & 0.764 \\
\hline & & 0.373 & 0.627 & 0.467 & 0.595 \\
\hline \multirow[t]{2}{*}{5.} & 60 & 0.508 & 0.492 & 0.709 & 1.033 \\
\hline & & 0.458 & 0.542 & 0.612 & 0.845 \\
\hline \multirow[t]{2}{*}{6.} & 65 & 0.583 & 0.417 & 0.875 & 1.400 \\
\hline & & 0.508 & 0.492 & 0.709 & 1.033 \\
\hline \multirow[t]{2}{*}{7.} & 70 & 0.632 & 0.368 & 1.000 & 1.717 \\
\hline & & 0.583 & 0.417 & 0.875 & 1.400 \\
\hline \multirow[t]{2}{*}{8.} & 75 & 0.756 & 0.244 & 1.411 & 3.098 \\
\hline & & 0.632 & 0.368 & 1.000 & 1.717 \\
\hline \multirow[t]{2}{*}{9.} & 80 & 0.829 & 0.171 & 1.766 & 4.848 \\
\hline & & 0.756 & 0.244 & 1.411 & 3.098 \\
\hline \multirow[t]{2}{*}{10.} & 85 & 0.829 & 0.171 & 1.766 & 4.848 \\
\hline & & 0.756 & 0.244 & 1.411 & 3.098 \\
\hline
\end{tabular}




\begin{tabular}{cccccc}
\hline 11. & & & & & \\
& & & & & \\
12. & & 0.6143 & 0.243 & 1.415 & 1.058 \\
& & 0.612 & 0.388 & 1.277 & 1.277 \\
13 & 95 & 0.567 & 0.388 & 0.947 & 1.309 \\
& & 0.589 & 0.433 & 0.837 & 1.433 \\
& & 0.453 & 0.411 & 0.889 & 0.828 \\
\hline
\end{tabular}

And from the graphs Figure 2 and 3 it was observed that for both white and red sorghum tested for sample a the order of kinetic is with first order, while with second order was obtained for white and red samples of $\mathrm{b}$ in Figure 4 and 5. Therefore, from the tested orders it can stated that the extract yield was favored more with first order as the gradient is less or equal to $1(0.87=1)$.

Proximate compositions of red Sorghum malt grains $(\%)$

Moisture content

Diastatic power ${ }^{0} \mathrm{~L}$ (DP) b - amylase mainly

A-Amino nitrogen (mg/1)

Total soluble nitrogen (TSN) $(\%)$

B-D- Glucan (\%)

Malting loss (\%)

Density

Ash content

Fat content

Crude fiber

Starch

Nitrogen

Crude protein

7.7
23.81
$32.3 \mathrm{mg} / 1$
2.12
Negligible
9.5
0.66
$0.175 \%$
$8.14 \%$
1.82
$64 \%$
1.26
5.52

Gravity in brewing industry is the level of sugar present in the brewed wort or eventual products produced from such, either beer or malt. The $\mathrm{pH}$ which is the level of either acidity or alkalinity of any substance are very important as the body intake of either acid or alkaline are monitor and regulated, to avoid any excess take a disorder. The result of the wort and Mucamalt analyzed are presented below.

$\begin{array}{ll}\text { Result of the Analyzed Wort } & \\ \text { Original gravity } & 4.09 \\ \text { PH reading } & 5.58 \\ \text { Colour of cold wort (EBC) } & 6.4 \\ \text { Odour } & \text { Aroma } \\ \text { Taste } & \text { Sweet } \\ \text { Turbidity (EBC) } & \text { Turbid }\end{array}$

$\begin{array}{ll}\text { Result of the Analyzed Mucamalt } \\ \text { Energy } & 220 \mathrm{kj} / 100 \mathrm{ml} \\ \text { Carbohydrate } & 10.48 \mathrm{~g} / 100 \mathrm{ml} \\ \text { Protein } & 0.25 \mathrm{~g} / \mathrm{mg} \\ \text { Fat } & 0.02 \mathrm{~g} / \mathrm{mg} \\ \text { Calcium } & 35 \mathrm{~g} / 100 \mathrm{ml} \\ \text { Vitamins A } & 2401 \mathrm{l} / 100 \mathrm{ml} \\ B_{1} & 0.11 \mathrm{mg} / 100 \mathrm{ml} \\ \mathrm{B}_{2} & 0.12 \mathrm{mg} / 100 \mathrm{ml} \\ \mathrm{B}_{3} & 0.97 \mathrm{mg} / 100 \mathrm{ml} \\ \mathrm{B}_{5} & 0.49 \mathrm{mg} / 100 \mathrm{ml} \\ \mathrm{B}_{6} & 0.18 \mathrm{mg} / 100 \mathrm{ml} \\ \mathrm{C} & 2.18 \mathrm{mg} / 100 \mathrm{ml}\end{array}$

\section{Optimum temperature for maximum extract yield of sorghum}

Optimum temperature is the temperature at which high percent of extract can be achieved which is $80^{\circ} \mathrm{C}$ and $85^{\circ} \mathrm{C}$; the percentage extract yield obtained is shown in the table above. Extract yield, is important in the determination of economic factors and evaluation of raw grain for malting and gotten thus: En $=75.49 \%$ and $\mathrm{Ed}=81.52 \%$ 
Tannin, is a yellowish or brownish bitter-tasting organic substance present in barks of the cashew apple fruits which are carried along in the course of extraction and this must be remove through precipitation using rice gruel, local rice are used to avoid the chemical been used to polished these foreign types. The original gravity of 4.09 was obtained which is the level of the sugar content and eventually determine the quantity of sugar syrup to be added, ${ }_{\mathrm{P}} \mathrm{H}=5.58$ and Taste is sweet.

The research results shows that favorably, Mucamalt produced with the vitamin $\mathrm{C}$ obtained from cashew apple fruits can best compare with the imported ascorbic acid and this can be seen from the analyzed three selected malts in the market. What is new here is the source of vitamin $\mathrm{C}$ and other vitamins which are essential to the body, and is has found in abundant in the source of vitamin used.

Analysis of the produced mucamalt and compared with three other malts variety in the market.

\begin{tabular}{|c|c|}
\hline Ingredients & Mucamalt \\
\hline Energy & $220 \mathrm{kj} / 100 \mathrm{ml}$ \\
\hline Carbohydrate & $10.48 \mathrm{~g} / 100 \mathrm{ml}$ \\
\hline Protein & $0.25 \mathrm{~g} / \mathrm{mg}$ \\
\hline Fat & $0.02 \mathrm{~g} / \mathrm{mg}$ \\
\hline Calcium & $35 \mathrm{~g} / 100 \mathrm{ml}$ \\
\hline Vitamins A & $2401 \mathrm{u} / 100 \mathrm{ml}$ \\
\hline $\mathrm{B}_{1}$ & $0.11 \mathrm{mg} / 100 \mathrm{r}$ \\
\hline $\mathrm{B}_{2}$ & $0.12 \mathrm{mg} / 100 \mathrm{r}$ \\
\hline $\mathrm{B}_{3}$ & $0.97 \mathrm{mg} / 100$ \\
\hline $\mathrm{B}_{5}$ & $0.49 \mathrm{mg} / 100 \mathrm{r}$ \\
\hline $\mathrm{B}_{6}$ & $0.18 \mathrm{mg} / 100$ \\
\hline $\mathrm{C}$ & $2.18 \mathrm{mg} / 100$ \\
\hline
\end{tabular}

Nasmalt
$\mathbf{2 0 6} \mathbf{k j} / \mathbf{1 0 0 m l}$
$10.52 \mathrm{~g} / 100 \mathrm{ml}$
$0.24 \mathrm{~g} / \mathrm{mg}$
$0.02 \mathrm{~g} / \mathrm{mg}$
$36 \mathrm{~g} / 100 \mathrm{ml}$
$3211 \mathrm{u} / 100 \mathrm{ml}$
$0.14 \mathrm{mg} / 100 \mathrm{ml}$
$0.13 \mathrm{mg} / 100 \mathrm{ml}$
$\mathbf{0 . 9 6} \mathbf{m g} / \mathbf{1 0 0 m l}$
$0.51 \mathrm{mg} / 100 \mathrm{ml}$
$0.18 \mathrm{mg} / 100 \mathrm{ml}$
$\mathbf{1 . 8 4 m g} / \mathbf{1 0 0 m l}$

Hi-malt
$\mathbf{2 1 8 k j} / \mathbf{1 0 0 m l}$
$11.44 \mathrm{~g} / 100 \mathrm{ml}$
$0.26 \mathrm{~g} / \mathrm{mg}$
$0.01 \mathrm{~g} / \mathrm{mg}$
$32 \mathrm{~g} / 100 \mathrm{ml}$
$2421 \mathrm{u} / 100 \mathrm{ml}$
$0.12 \mathrm{mg} / 100 \mathrm{ml}$
$0.13 \mathrm{mg} / 100 \mathrm{ml}$
$\mathbf{0 . 9 4 m g} / \mathbf{1 0 0 m l}$
$0.57 \mathrm{mg} / 100 \mathrm{ml}$
$0.19 \mathrm{mg} / 100 \mathrm{ml}$
$\mathbf{2 . 3 2} \mathbf{m g} / \mathbf{1 0 0 m l}$

Maltina
$\mathbf{2 2 7 k j} / \mathbf{1 0 0 m l}$
$12.8 \mathrm{~g} / 100 \mathrm{ml}$
$0.38 \mathrm{~g} / \mathrm{mg}$
$0.09 \mathrm{~g} / \mathrm{mg}$
$53 \mathrm{~g} / 100 \mathrm{ml}$
$2451 \mathrm{u} / 100 \mathrm{ml}$
$0.13 \mathrm{mg} / 100 \mathrm{ml}$
$0.15 \mathrm{mg} / 100 \mathrm{ml}$
$\mathbf{0 . 9 8} \mathbf{m g} / \mathbf{1 0 0 m l}$
$0.52 \mathrm{mg} / 100 \mathrm{ml}$
$0.20 \mathrm{mg} / 100 \mathrm{ml}$
$\mathbf{2 . 5 7} \mathbf{m g} / \mathbf{1 0 0 m l}$
alcium which is more noticeable compared to others. Thus it depends on the adaption of an individual brewery to regulate their vitamin $\mathrm{C}$ cropping in their products. And the objective here is to seek more alternative source of producing malt drinks which this work has effective addressed in the area of major raw material such as carbohydrate (starch) source: sorghum and vitamin C (cashew) source which are all local content and in effect has direct impact on the final cost of production.

\section{Cashew apple juice extraction}

The red elongated cashew average weight obtained without nuts $=82.88 \mathrm{~g}$, Physical and water content of the red elongated cashew apple: Ave. wt., 82.88g, ${ }_{\mathrm{p}} \mathrm{H}$ 5.4, Juice cont. 62.05g, Substrate cont. 20.83g, Water cont. $74.87 \%$.

\section{Annual profits earnings calculation}

From the grand total cost of N9, 345.45 to produced 206.2bottles, (8.6crates) while cost of producing a bottle stood at N45.32 and crate cost N1,087.73. Assumed $15 \%$ of the cost of production is used as handling and packaging charges, therefore, the cost per crate now will be N1, 250.89

Six (6) crates of Mucamalt will therefore be,

= N2, 021,638.38 and @ N157 to Dollar=\$12,876.678

Supposed a crate of Mucamalt is sold for N1, 600 (\$10.191) per crate

Therefore, $1,616.16$ crates will cost $(1,616.16 \times 1,600)$

$$
=\$ 16,470.42
$$

Profit per brew on $160 \mathrm{HL}$ per day will be:

$\$(16,470.42-12,876.678)=\$ 3,593.74$

Annual profit at 329days per year $=\$ 3,593.74 \times 329=\$ 1,182,340.46$

\section{Conclusion}

The results of the various analysis conducted shows favorably. Mucamalt produced with the vitamin $\mathrm{c}$ obtained from cashew apple fruits can compare with the imported ascorbic acid and this can be seen from the analyzed three selected malts in the market. What is new here is the source of vitamin c and other vitamins which are essential to the body, and is has found in abundant in the source of vitamin used. Though there are some variations in the quantity of other ingredients, such as fat, vitamin c, protein and calcium which is more noticeable compared to others, thus it depends on the adaption of an individual brewery to regulate their vitamin c cropping in their products. And the objective here is to seek alternative source of producing malt drinks which this work has effectively addressed, in the area of major raw material such as carbohydrate (starch) source: sorghum and vitamin c (cashew) source which are all local content and in effect has direct impact on the final cost of production. 


\section{Acknowledgements}

I acknowledge with gratitude and sincerely thank Almighty Allah (SWT) for his abundance grace and wisdom.

\section{References}

[1]. Aluko, A. O. (1989). Cereal Science today. Rev. Biotechnology, 12: 259

[2]. Aniche, G. N. \& Palmer, G. H. (1990). Journal of the Institute of Brewing, 96 \& 377.

[3]. Aries, R. S. \& Newton, R. D. (1955) Cost Estimation (McGraw- Hill).

[4]. Asien, A. O. (1982). Journal of the Institute Brewing, 88 and 164.

[5]. Ayoola, M. O. (1993). Malting-brewing characteristics of pennisetum typhoides \& pennisetum maiwa, Mat. 93/3951

[6]. Baasel, W. D. (1965) Chem. Eng., NY 72 (Oct. 25th) 147. Exploring response surfaces to establish optimum conditions.

[7]. Bawa, D. \& Yoshiyuki A (1993). Comparison of the Malt Characteristics of Traditional and Improved Varieties of Sorghum Vulgare from Ghana, Vol. 99., 227- 230

[8]. Beightler, C. S. \& Wilde, D. J. (1967) Foundations of Optimisation (Prentice-Hall).

[9]. Beveridge, G. S \& Schechter, R. S (1970), Optimization: Theory and Practice, McGraw-Hill, New York

[10]. Briggs, D. E., Haogh, J. S., Stevens R \& Young, T. W. (1981). Malting \& Brewing Science" $2^{\text {nd }}$ ed. Vol. 1 Malt and Sweet Wort, Chapman and Hall, London. 295-353.

[11]. Chilton, C. H. (1960) Cost Engineering in the Process Industries (McGraw-Hill).

[12]. Dada, D. Head Brew Master, (1992). Noble Breweries Limited, Ijagbo-Offa, Kwara State. Experience as Laboratory Analyst.

[13]. Daiber, K.H. \& Taylor, J.R.N(1995). Opaque beers. In 'Sorghum and Millets: Chemistry and Technology', (D.A.V. Dendy, ed.), American Association of Cereal Chemists, St. Paul, USA, 299-323.

[14]. Daiber, K. H. \& Novellie, L. (1962). Journal of the Science of Food and Agriculture, 19 and 87.

[15]. Daiber, K. H. \& Novellie, L. (1973). Sorghum malting and brewing studies. Part 22.

[16]. The modification of Sorghum Malt. Brauwissenschaft, 26 and 220-248

[17]. Demuyakor, B. \& Ohta, Y. (1991). Food Microbiology, 8 and 183.

[18]. Demuyakor, B. \& Ohta, Y. (1992). Journal of the Science of Food and Agriculture, 59 and 457.

[19]. Ekundayo, J. A.(1969). Journal of Food Technology, 4 and 217.

[20]. Etokakpan, O. U. (1988). Biochemistry Studies of the Malting of Sorghum and Barley. PhD Thesis. Heriot-Watt University, Edinburg.

[21]. Faparusi, S. I. (1970). Sugar changes during the preparation of Burukutu beer, Journal of the Science of Food and Agriculture, 21 \& 79-81.

[22]. Filgueiras, H. A. C., Alves, R. E., Mosca, J. L., \& Menezes, J. B. International Symposium Effect of Pre and Postharvest factors in fruit Storage cashew Apple Fresh Consumption

[23]. Glennie, C. W., Harris, J. \& Liebenberg, N. V. D. W. (1983). "Endosperm modification in germinating sorghum grain" Cereal Chemistry, 60 and 27-31.

[24]. Gomez, M. I. (1992). Screening of sorghum for malting and use. Agriculture of sorghum symposium (SADCC/INCRISAT). Bulawayo. Zimbabwe

[25]. Guthrie, K. M. (1969) Chem. Eng., NY 76 (March 24th) 114. Capital cost estimating.

[26]. Hnyrup, H. E.(1964) "Beer and Brewing," Kirk-Othmer Encyclopedia of Chemical Technology, Volume 3, John Wiley and Sons, Inc., New York,

[27]. Hough, J. S. (1985). The Biotechnology of Malting and Brewing Cambridge, London: Cambridge University Press.

[28]. Hough, J. S. (1977). Development of brewing Analysis. A Historical review. The Institute of Brewing, London,12.

[29]. Hough, J.S,. Briggs, D.E, \& Stevens R (1977). Malting and Brewing Science. Chapman and Hall London. Igyor, M. A. (1987). Studies on Malting and Mashing with Sorghum M. Sc. Thesis. Heriot-Watt University, Edinburgh.

[30]. Kalu N. I. (2007). Hand-out on Introduction to malting Science, Abia State University, Industrial Chemistry Dept.

[31]. Kent L. N. (1983). Technology of Cereals" $3^{\text {rd }}$ ed. Pergamon press Oxford,16-48

[32]. Kunze, W. (1996). Technology malting and brewing. VLB Germany. 120-250, 253-259.

[33]. Lower, S. T. \& Agyente-Badu, C. K. (2009), The Natural Food Hub, "Natural food Fruit Vitamin C Content", Food Res. Technology (2000), Morton, J. (1987) Cashew Apple. p. 239-240. In: Fruits of warm climates. Julia F. Morton, Miami, FL.

[34]. Lyda, T. B. (1972) Chem. Eng., NY 79 (Sept. 18th) 182. How much working capital will the new project need?

[35]. Morall, P., Boyd, H. K. Taylor, J. R. N., \& Van Der Walt, W. H. (1986). "The Effects of Germination, Time, Temperature and Moisture content on malting of sorghum". Journal of the Institute of Brewing, 92 \& 439-445.

[36]. Novellie, L. (1959) The Journal of the Science of Food and Agriculture, 10 and 441.

[37]. Nweke, F.I, Ibe, D.G. (1989). Nigeria Agriculture and Brewing; A new symbiosis Symposium for brewing industry,13-16.

[38]. Ogundiwin. J. O. \& Tehinse, J. F. (1981) Brewing \& Distilling International, 11 \& 42 Olugbenga, O. J. (2006) "Studies of the brewing attribute of maize, 2006/24146EH

[39]. Okafor, N. (1987). Industrial Microbiology. 1st edition University of Ife Press, 174- 182.

[40]. Okolo, B. N, \& Lewis I. E. (1995). Enhancement of amylolytic potentials of sorghum malt. J. Inst. Brew., 102: $267-274$.

[41]. Palmer, G. H., Etokakpan, O. U., \& M.A Igyor (1989). Sorghum as brewing material MIRCEN Journal, 5 and $265-275$.

[42]. Palmer G. H. (1992), Sorghum food beverage and brewing potentials, Process Biochemistry, 27 and $145-153$.

[43]. Palmer, G.H.(1989). Cereals for malting and brewing. In 'Cereal Science and Technology' (G.H. Palmer, ed.) Aberdeen University Press, Aberdeen, UK, 61-242.

[44]. Pollock, J. R. A (1979) “Brewing Science” Food Science and Technology vol. 3, Academic Press London, 330 and 331

[45]. Pollock, J.R.A. (1981). Brewing science. Academic press New York and London, 2.

[46]. Rooney, L.W. \& Waniska, R.D(2000). Sorghum food and industrial utilization. In Sorghum: Origin, History, Technology, and Production, (C. Wayne Rose, A.H. (1989). The microbial production of food and drinks. The advent of genetic engineering and food Microbiology. A handbook of Microbiology, 45-54.

[47]. Smith, E.Y. (1996). Introduction to Biotechnology. Academic press, New York, $1^{\text {st }}$ ed,185-186.

[48]. Virander, K. C.(2012). Head Brew Master, Benue brewing limited Makurdi, BenueState.

[49]. Zepka, Leila Q., Mercadante, \& Adriana Z. (2008), "Degradation products formed during carotenoid heating in a simulated cashew apple juice" (Print), 5th Pigments in Food congress- for quality and health, University of Helsinkis http://en.wikipedia.org/wiki/sorghum-wikipedia, the free encyclopedia. 